\title{
EXPANSION OF THE SIMPLE SENTENCES BY MEANS OF THE VERB COMPOUNDS IN FRENCH AND AZERBAIJANI
}

\author{
РОЗШИРЕННЯ ПРОСТИХ РЕЧЕНЬ ЗА ДОПОМОГОЮ ДІССЛІВНИХ \\ СЛОВОСПОЛУЧЕНЬ В АЗЕРБАЙДЖАНСЬКІЙ І ФРАНЦУЗЬКІЙ МОВАХ
}

\author{
Gasimova I. \\ orcid.org/0000-0002-0009-7477 \\ PhD Student of the Department of Foreign Languages \\ Nakhchivan State University
}

Cultural, literary, economical, and so on relationships among the people of the world also affect languages and cause their similarities and differences to emerge. In this sense, it is one of the most interesting issues to uncover the relationship between the Azerbaijani and French languages. Problems such as justification of the need for simple sentence expansion in both Azerbaijani and French languages, clarifying the meaning of simple sentence extensions in both languages, and defining the main features and types of simple sentence extensions can be identified as a result of grammatical comparison of languages. In addition, the opening of a simple sentence in the Azerbaijani and French languages through the members is one of the issues that we need to solve in our modern age. Today, the world is in a culture of development with a growing number of humanitarian ties between nations. These connections strengthen the process of rapprochement of nations around the world, and the need for mutual understanding and dialogue between nations and nations is needed. Numerous facts make comparative scientific and theoretical analyzes between the French and Azerbaijani languages a natural process. However, the words of walking hardly in the sentence take part as to serve as an independent member, expansion its views and ideas. All formal and meaningful changes in the sentence occur on a nuclear basis so that in the process of enlargement of the sentence it is possible to convert a least verbal sentence into a multilayer structure. Therefore, verb combinations, which are considered to be one of the means of expanding simple sentences in these languages, have been involved in the study. The study of the languages of different peoples of the world is not limited to the study of grammatical rules. In this process, it is possible to get acquainted with the facts revealing the cultural level, social and political views of the individual countries, their aesthetic tendencies. This, on the one hand, promotes the development of literary and cultural relations between a number of countries.

Comparative study of languages plays a great role in the acquaintance and communication of the Azerbaijani people with the Western world. In this sense, France and Azerbaijan have historical and cultural basis. Comparative research between languages is also useful in terms of studying the history of cultures.

Key words: word, member, sentence, extension, verb combination.

Культурні, літературні, економічні та ін. стосунки між людьми світу також впливають на мови та зумовлюють їх схожість та відмінності. У цьому сенсі одним із найцікавіших питань $є$ розкриття зв'язку між азербайджанською та французькою мовами. Такі проблеми, як обґрунтування необхідності простого розширення речень у азербайджанській та французькій мовах, уточнення значення простих розширень речень в обох мовах та визначення основних ознак і типів простих розширень речень, можуть бути визначені в результаті граматичного порівняння мов. Крім того, відкриття простого речення у азербайджанській та французькій мовах через члени є одним із питань, які нам потрібно вирішити в сучасну епоху. Нині світ перебуває в процесі розвитку, де зростає кількість гуманітарних зв'язків між націями. Ці зв'язки посилюють процес зближення націй у всьому світі і необхідність взаєморозуміння та діалогу між націями та народностями. Численні факти роблять порівняльний науковий та теоретичний аналіз між французькою та азербайджанською мовами природним процесом. Однак слова, що йдуть навряд чи в реченні, беруть участь у тому, щоб служити самостійним членом, розширювати свої погляди та ідеї. Всі формальні та змістові зміни в реченні відбуваються на ядерній основі, отже, в процесі збільшення речення можна перетворити найменше словесне речення на багатошарову структуру. Тому у дослідженні були залучені дієслівні сполучення, які вважаються одним із засобів розширення простих речень цими мовами. Вивчення мов різних народів світу не обмежується вивченням граматичних правил. У цьому процесі можна ознайомитись з фактами, що розкривають культурний рівень, соціальні та політичні погляди окремих країн, їх естетичні тенденції. Це сприяє розвитку літературних та культурних зв'язків між низкою країн.

Порівняльне вивчення мов відіграє велику роль у знайомстві та спілкуванні азербайджанського народу із західним світом. У цьому сенсі Франція та Азербайджан мають історичну та культурну основи. Порівняльне дослідження мов також корисне з точки зору вивчення історії культур.

Ключові слова: слово, член, речення, продовження, сполучення дієслів.

Introduction. Studies in French and Azerbaijani languages confirm that all the changes in the sentence are based on the main members, that is, the news and the news. It is known that the main members form the nucleus of the sentence. All formal and meaningful changes in the sentence occur on a nuclear basis so that in the process of enlargement of the sentence it is possible to convert a least verbal sentence into a multilayer structure.

For example, often a simple sentence can only contain information and news. By expanding it with one or more secondary members, it is possible to obtain 
the structure of the sentence by its form and meaning. In this sense, the role of sentence elements expressed in verb combinations is also important. The article cites the main reason for the expansion of the sentence as its change by earning additional members, and notes that as the sentence changes, additional members gain. The need for these two processes is confirmed and their coherence is established. The fact that French and Azerbaijani grammatical material changes the sentence's verbs through combinations results in both acquiring new features and acquiring new functions.

Analysis of recent research and publications. The study of the languages of different peoples of the world is not limited to the study of grammatical rules. In this process, it is possible to get acquainted with the facts revealing the cultural level, social and political views of the individual countries, their aesthetic tendencies. This promotes the development of literary and cultural relations between countries. Comparative study of languages plays a great role in the acquaintance and communication of the Azerbaijani people with the Western world. In this sense, France and Azerbaijan have historical and cultural basis. Comparative research between languages is also useful in terms of studying the history of cultures. Today, the world is in a culture of development with a growing number of humanitarian ties between nations. These connections strengthen the process of rapprochement of nations around the world, and the need for mutual understanding and dialogue between nations and nations is needed. Numerous facts make comparative scientific and theoretical analyzes between the French and Azerbaijani languages a natural process.

For the first time, the study reveals a number of problematic features in French and Azerbaijani grammar, revealing the grammatical links between the languages in order to thoroughly and comprehensively study simple syntax of interesting and relevant topics in grammar. In this sense, the dedication of the study to the problem of the expansion of the simple sentence in French and Azerbaijani through the combination of verbs indicates its relevance. In the study, the expansion of simple sentences in French and Azerbaijani languages is presented as a problem and the role of syntactic units in the process is highlighted. In this regard, research on verb combinations is underway. It is known that combinations are used as syntax members in syntax. Since one of the means of enlargement of a simple sentence is also a member of a sentence, verb combinations approach this aspect. The study identifies the characteristics of verb combinations in terms of form and meaning.
Discussion. It is possible to meet with different sentences structures in the syntactic structures of the world languages. No doubt, many innovations and events, some specific features show itself in the development of the languages. On the view of the development of these events many similar and different features appearing in some languages of the world.

French and Azerbaijani has similar features for their sentences structure. The changings in both languages have similar features. Especially expansion of the simple sentences by the mean of different ways.

The verbal language facts takes an important place in the expansion process of the simple sentences in French and Azerbaijani. In this sense, undefined forms of verb play an important role in the expansion of sentences. Conversational language facts and literary language examples confirm that the undefined forms of the verb do not lag behind other language units in expanding the sentence both visually and logically.

When you look at examples from both languages, this statement is reflects itself:

The man was walking hardly and looking.

In this sentence, the grammatical basis - the subject and the predicate (the man was looking) expresses a completed idea and give some information about the main work. In other words, the sentence is complete even if there are no other words in the sentence. However, the words of walking hardly in the sentence take part as to serve as an independent member, expansion its views and ideas. Here the answer of how the man looks? Question formed on the basis of adverbial is interesting by two aspects:

1. These words extend the sentence from the gloss point of view, that is, a two-member sentence becomes a syntactic unit of three members.

2 . The verb combination that is added to the sentence, that is, the adverbial of the syntactic unit, also justifies the expansion of thought. So the sentence answering the questions of who? what did? demands three questions as who? how? what did? And it plays an important role in the delivering of the ideas.

While looking the materials belong to French, we meet the same view. In this language, verb combinations play an important role in expanding and changing simple sentences in terms of opinions and sentences.

Let's look the following sentences:

Robert s'était arrêté en baissant la tête

Un homme parlant quatre langues se mit a travailler dans cette entreprise.

Une fenêtre donnant sur la cour était cassée.

D'entendre parler de lui, d'entendre son nom la rendait heureuse.(Rolland) [4, p. 201]. 
The verb combinations have three forms in Azerbaijani:

1. The objective with the infinitive construction. Example: To read well. He tried to read well.

2. The objective participial construction. Example: The man coming from far city. The quest coming from further city was scientist.

3. The adverbial participial construction. Example. While coming home. While coming from home I met with my friend.

Here the words he was trying, the guest was a scientist, I saw worked as key members carrying the information load of the main idea.

But reading well, coming from a distant city, going home verbal word combination are differ from it. They are the main reason of diversification. Thus, the verb combinations in the first sentence are intended for the purpose, the verb combinations in the second sentence are defined, and the verbs in the latter sentence function as the adverbial of the sentence, improving the sentences both in form and content.

We meet the upper process in French too.

Apprendre ne suffit pas, il faut sentir, il faut comprendre (Daudet) [4, p. 201].

Attendre est dur, quand on ne peut rien faire (Bosco).

Il sortit sans dire un mot

On l'accuse d'avoir tué un homme [4, p. 203].

C'étaient des touristes revenant du Midi.

On voyait dans la foule des femmes pleurant de joie.

Un homme pâle et marchant péniblement sortie d'une petite maison.

Les touristes arrivés à Moscou descendent à l'hôtel.

En discutant d'homme à homme on parvient parfois

à s'entendre (Dorgelès) [4, p. 235].

Tout en dinant, il lisait le journal.

In our view, the issue of sentence expansion has emerged as one of the events that characterizes the formation and development of the language in the post-early stages of the emergence of languages. The language does not like stagnation, it is always more or less developed. During this development, words, expressions, sentences are updated and refined, and are linked to a number of facts and events that occur in the language. These relationships justify a different content and form. The French and Azerbaijani facts show that a simple sentence is not extend itself. It must be the situation for the expansion in the structure of sentence and the changes related with it.

The fact materials in both languages show that a simple sentence, consisting of one or two members, can be arranged in the form of an extended sentence of five members - all members of the sentence. This demonstrates the process of syntactic units of simplicity to complex in languages.

It is natural the occurrence of the new relations among the members of the sentences during the expansion of the simple sentences. But the expansion process is not enough. In this process, there is an expansion of form and content that reinforces the form-content dependency. This relationship is one of the key issues in expanding the sentence. As a simple sentence expands, the number of words that make up it increases with its functions and it is very important in the filling of the mind. As the sentence expands, its purpose is more clearly understood, and the ideas presented there are more readily understood. Sentence expansion is one of the natural and necessary processes in the scientific and theoretical languages. The expansion of a simple sentence reveals the following processes:

1. The functional units of the sentence is increasing.

2. Functional differences forms in the sentences.

In the expansion, the number of affiliations that belong to any member of a sentence is increasing and becoming more relevant.

Expanding a simple sentence is one of the best ways to convey an idea. That is, this process is linked to a specific purpose. The grammatical base of the sentence is used in a number of ways, with its modification leading to a change in the structure as a whole. Therefore, the number of sentences in the sentence is growing, which helps to understand the message being conveyed.

The part formed by the extension of the simple sentence are not ordinary words. Thus, after joining the sentence, they communicate with other parts. These relationships serve to build the sentence correctly, to convey the meaning of the words and thus to convey the message.

The researches on French and Azerbaijani show that there are key members (subject and predicate) based on all the changes in the sentence. Thus, the main members form the nucleus of the sentence. Structural changes occur at the core of the nucleus. By extension, a simple and least-worded structure can be transformed into a complex and multi-word structure. For example, while a simple short sentence can only contain information and news, it is possible to obtain the perfect form and meaningful plant syntactic unit by adding one second member or all secondary members. For example: Even though the sentence I have never seen consists of two components, the number of members in the sentence I've never seen is three in the first sentence. When we say I've never seen cit- 
ies, the number of members is growing. In the phrase I have never seen these cities, the former landscape changes, and all the members of the sentence - five of them - get the whole structure with the perfect structure. The same can be said for the French.

Le professeur (à qui?) m'a donné un devoir (Complément d'objet).

Sur son visage, il y avait un sourire (comment?) joyeux (Attribut).

(Quand?) Aujourd'hui, plein de gens apprennent le russe (Ct.circ.de temps).

Les étudiants apprennent(Comment?) constamment (Ct.circ.de maniere).

Les feuilles de vigne dessinaient leurs ombres sur le sable (Ct.circ.de lieu).

So, by working on all short sentences, they can be transformed into broad sentences. Increasing the number of members in the sentence, on the one hand, draws attention to their attitudes at first sight, and on the other hand, reveals the deeper relationships of the words. By explaining the essence of the words or phrases (sentence members) added later to the sentence, the idea of an invariant (abstract) meaning of the idea is also identified. In this sense, the sentence's semantics appear after the initial variant.

Research confirms that the main reason for the expansion of the sentence is its gain by adding additional members, or vice versa, as the sentence changes, additional members gain. Thus, the two processes are necessary here. These processes are closely intertwined. Factual materials of French and Azerbaijani grammar show that the following two changes in the sentence are related to its expansion:

1. The sentence, which has become extend, gets a new form.

2. It acquires a new form, as well as a new function. The sentence, which has become extend, gets a new form.

The expansion of a simple sentence, of course, increases the number of sentences and does not change the structure. What is changing here is that the sentence has an increasing number of members. In this process, all the words that play the part of the sentence, that is, the key parts of the speech, play a role.

Conclusions. Researches on French and Azerbaijani language materials show that the verb adjectives are of particular importance in terms of adjectives, extensions and their constituents (verb combinations).

Thus, investigations based on French and Azerbaijani materials again confirm the grammatical similarities between the languages of the world.

\section{REFERENCES:}

1. Abdullayeva G. Modern Azerbaijan language. Baki : Science and education, 2013, 308 p.

2. Asgarova M. The grammer of French. Nakhchivan : Ajami, 2017, $142 \mathrm{p}$.

3. Khalilov B. Modern Azerbaijan language (syntax). Baki : Adiloglu, 2017, 428 p.

4. Guliyeva M. Short information about the grammer of French. Baki : Azertadrisnashr, 1962, $92 \mathrm{p}$.

5. Steinberq N. The grammer of French. The II volume. Leningrad, 1972, $214 \mathrm{p}$. 